\title{
Hepatocytes respond differently to major dietary trans fatty acid isomers, elaidic acid and trans-vaccenic acid
}

Toke P. Krogager, Lone Vendel Nielsen, Derya Kahveci, Thomas F. Dyrlund, Carsten Scavenius, Kristian W. Sanggaard and Jan J. Enghild

\begin{abstract}
Background: It has been discussed if the adverse health effect associated with the ingestion of trans fatty acids correlates with the food source, as the composition of the isomers varies in different foods. We have investigated the hepatocellular responses to the predominant trans fatty acid isomers in industrially produced partially hydrogenated vegetable oils (elaidic acid) and products of ruminant origin (trans-vaccenic acid).

Results: The responses of HepG2-SF cells exposed to $100 \mu \mathrm{M}$ fatty acids during 7 days were examined. Elaidic acid decreased the cellular proliferation rate while trans-vaccenic acid had no effect. Analysis of cellular triacylglycerol fractions showed, that both trans fatty acids were metabolized by HepG2-SF cells, although elaidic acid, to a higher degree than trans-vaccenic, accumulated in the triacylglycerol fraction. Proteome analysis revealed that the overlap of differentially regulated proteins only contained four proteins, suggesting that the two trans fatty acid isomers affect the cells in different ways. The data are available via ProteomeXchange with identifier PXD000760.

Conclusions: Our investigations revealed that the hepatocellular response to the two most abundant dietary positional C18:1 trans fatty acid isomers differ substantially. In addition, the results suggest that trans-vaccenic acid does not affect cholesterol metabolism adversely compared to elaidic acid.
\end{abstract}

Keywords: Cardiovascular disease, Lipid metabolism, Trans fatty acid, Proteomics, SILAC

\section{Background}

Trans fatty acids (TFA) in the human diet originate from industrial partial hydrogenation of vegetable oils (iTFA) and the naturally occurring TFA in milk and body fat of ruminants (rTFA). The intake of iTFA can reach $9 \%$ of the total energy intake [1] whereas the intake of rTFA rarely exceeds $0.5 \%$ [2]. Dietary iTFA causes increased ratios in plasma of total cholesterol and LDL-cholesterol to HDL-cholesterol and of apoB to apoA1, therefore, increasing the risk of cardiovascular disease (CVD) (reviewed in [3]). The impact of rTFA on human health has also been investigated, but the results have been inconclusive (reviewed in [4]). Most studies do not show a relationship between rTFA and CVD [5-7] although a few have indicated an inverse association $[8,9]$. In contrast to this

\footnotetext{
* Correspondence: jje@mbg.au.dk

Department of Molecular Biology and Genetics and iNANO, Aarhus University, Gustav Wieds Vej 10C, 8000 Aarhus C, Denmark
}

potential positive effect of rTFA in relation to CVD, a high concentration of rTFA in serum and erythrocytes results in an increased risk of breast cancer [10, 11].

The main iTFA isomer is the trans $\triangle 9$-C18:1 named elaidic acid (EA), whereas the main isomer of rTFA is the trans $\triangle 11-\mathrm{C} 18: 1$ named trans-vaccenic acid (trans $\mathrm{VA}$ ) (40-60 \% of rTFA [12]). The transVA originates from incomplete biohydrogenation of polyunsaturated fatty acids by microorganisms in the rumen of cows, goats and sheep [13]. Besides from being the major rTFA, transVA is also a constituent of iTFA contributing up to $5 \%$ of the fat in margarine and shortening. Additionally, EA is present in rTFA, where it may constitute up to $10 \%$ of the total rTFA [12]. Consequently, both EA and transVA intake may originate from several sources, complicating the evaluation of the impact of the individual isomer on human health. It is possible to enrich ruminant products for transVA through feeding strategies, by increasing time 
on pasture and decreasing silage in cattle feed, but the effect on EA content has not been evaluated [14]. TFA isomer distribution and content in iTFA varies depending on starting oil, degree of hydrogenation, temperature and catalyst $[15,16]$. Knowledge about responses to individual TFA isomers such as EA and transVA can contribute in developing guidelines for the process of partial hydrogenation of vegetable oils and food formulations by the industry, but also in the context of feeding strategies for milk and meat production.

Despite indications that differential responses to positional isomers exist $[17,18]$, to our knowledge the TFA isomer specific effects in human have not been directly investigated through dietary intervention studies. Human clinical studies comparing health impact of diets enriched in dairy products with diets rich in hydrogenated vegetable oils exist [19-21]. However, the effect caused by the particular TFAs was difficult to ascertain because both diets contained TFA mixtures with isomers in different amount. In other studies, TFA replaced saturated fatty acids or polyunsaturated fatty acids to keep calorie-intake constant between experimental diets [22, 23]. The result of these studies is likely a mixed effect of excluding some fatty acids and including others, and it is difficult to determine the effects of particular dietary TFA isomers [4]. Only few studies have been conducted on cultures of human cells to assess isomer specific responses in regards to CVD risk. The studies have focused on inflammatory markers in endothelial cells [24] and monocytes [25], and the results indicate, that EA is the most detrimental of the fatty acids, while transVA may even be anti-inflammatory.

Besides inflammatory conditions, a significant factor in development of CVD is the dysregulation of cholesterol and lipoprotein levels. The liver is responsible for the secretion and regulation of plasma proteins. In addition, ingested fatty acids are metabolized by the liver and together with cholesterol redistributed to other organs through lipoproteins. Thus, the hepatocyte responses to individual TFAs are essential for understanding the physiological effect of the intake of different TFAs.

Through proteomic, we have evaluated if human hepatocellular cell line, HepG2-SF, responses to supplemented EA and transVA are comparable by reference to their cis-isomers, oleic acid (OA) and cis-vaccenic acid (cisVA). The cellular response to the TFAs EA and transVA were compared and investigated by reference to their naturally occurring cis-isomers OA and cisVA. Due to cellular desaturation of transVA into conjugated linoleic acid (CLA) this fatty acid was also included. The concentration of total free fatty acids in human blood has been reported to be as high as $435 \pm 11 \mu \mathrm{M}$ and that of a single free fatty acid, such as oleic acid, can be as high as $158 \pm 5 \mu \mathrm{M}$ [26]. Previous studies of HepG2 cells showed physiological relevant responses to free fatty acids (ranging from 50 to $1000 \mu \mathrm{M}$ ) and further HepG2 cells expressed and secreted a broad range of known plasma proteins important to lipid metabolism [27-33]. The lower concentration range of free fatty acids (50$200 \mu \mathrm{M})$ only had a small effect on the cells $[29,31]$, whereas the free fatty acids were cytotoxic at higher concentrations [28]. These previous studies using HepG2 cells mainly investigated OA, EA and palmitic acid in relations to changes in cholesterol and lipoproteins levels. We used $100 \mu \mathrm{M}$ free fatty acid in complex with human serum albumin, which mimics the natural transportation of free fatty acids in the blood when fatty acids are not transported as lipoproteins [32]. Further, we used the commercial available HepG2-SF cell line adapted to growth in serum free media (commercial available as SynQ), which contains a minimal fatty acid formulation (see Methods), this gives us crucial control of the presence of fatty acids in the cell culture media supplemented with the experimental fatty acids.

We used Stable Isotope Labeling by Amino acids in Cell culture (SILAC) to investigate both cellular and secreted proteins from HepG2-SF cells in two separate triplex setups where cells were supplemented with transVA, cisVA or EA and transVA, OA or CLA. This was chosen because of the limitation of multiplexing more than three groups with SILAC. Further, Difference in gel electrophoresis (DIGE) was used to investigate the secretome from HepG2-SF cells supplemented with EA, $\mathrm{OA}$ or cisVA. Special emphasis has been on analyzing the secretome of EA and transVA supplemented cells, as changes in particular plasma protein levels are essential in the progression of CVD.

\section{Results}

\section{Viability of HepG2-SF cells in fatty acid supplemented} medium

HepG2-SF cell viability in $100 \mu \mathrm{M}$ fatty acid supplemented medium was analyzed using CyQuant NF proliferation assay, as some $\mathrm{C} 18$ unsaturated fatty acids may be cytotoxic for HepG2 cells at or above $100 \mu \mathrm{M}$ [34]. During 7 days exposure, HepG2-SF cells were found viable in the presence of $100 \mu \mathrm{M}$ of all the fatty acids tested (Fig. 1). Proliferation did not significantly differ between cisVA and transVA and these did not differ markedly from Control (no fatty acid supplementation) either. Cells supplemented with CLA and OA did not significantly differ from Control in cell numbers on day 7, however, CLA and OA supplemented cells showed lower proliferation rates at the beginning of the experimental period. Supplementation with EA causes a considerable decrease in proliferation rate as compared to the other experimental groups, which suggests that EA directly or indirectly inhibit proliferation. 


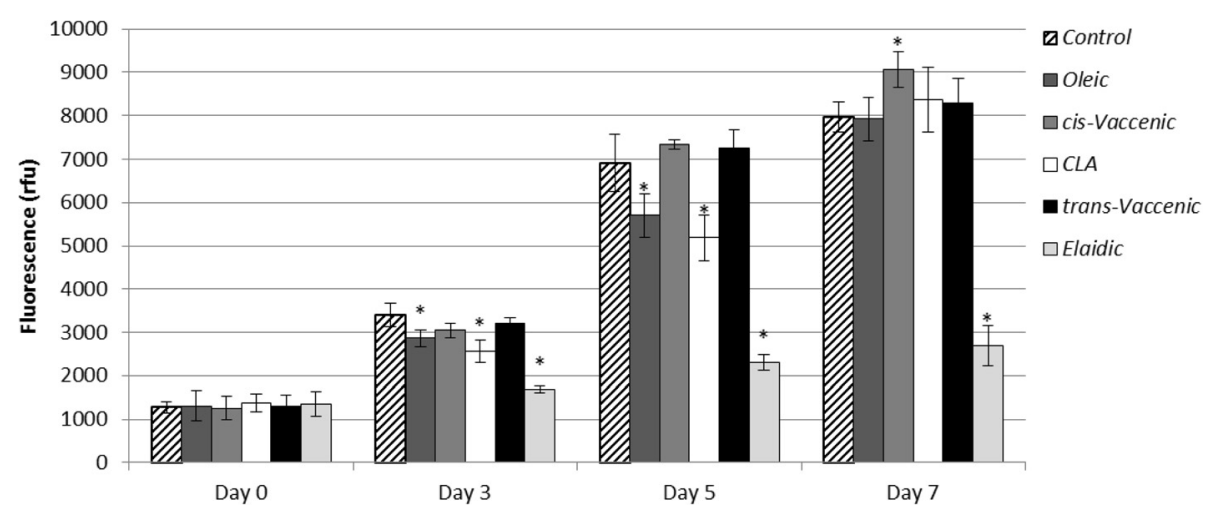

Fig. 1 Viability and proliferation of HepG2-SF cells in fatty acid supplemented medium. Viability of HepG2-SF cells in medium supplemented with $100 \mu \mathrm{M}$ OA, cisVA, CLA, transVA, EA, or no fatty acid (Control) was investigated using CyQuant proliferation assay. The measured fluorescence (y-axis) corresponds to live cell numbers. During a seven days period cisVA, trans-VA, and Control do not markedly differ in proliferation rate, whereas EA, though still viable, appear to be compromised on their proliferation. ${ }^{*}$ significantly different from Control at $p<0.05$

\section{Fatty acid esterification into TG of HepG2-SF cells}

To test if the supplemented fatty acids were taken up by the HepG2-SF and incorporated into TG, the fatty acid composition of FAME derived from the HepG2-SF TG fraction was analyzed by gas-liquid chromatography (Fig. 2 and Additional file 1: Data S1). The result showed that HepG2-SF cells take up the different supplemented fatty acids and esterify them into their TG. Eukaryotes are not able to make the fatty acid double bond of the trans geometry, and so Control and cells supplemented with cisVA do not contain TFA. Upon cisVA supplementation the content of this fatty acid in cell TG increase from $(8.3 \pm 4.2) \%$ to $(24.1 \pm 7.4) \%$ (i.e. the supplemented cisVA corresponds to $15.8 \% \pm 8.5$ of total TG derived FAME). Supplementing HepG2-SF cells for 7 days with transVA, this fatty acid is present at $9.5 \% \pm 1.1$ of the TG (Fig. 2a). The relative amounts of the supplemented geometrical isomers transVA and cisVA added to HepG2-SF TG are thus comparable $(9.5 \% \pm 1.1$ and $15.8 \% \pm 8.5)$. This is in contrast to the relative amounts of the positional trans-isomers EA and transVA, which are very different, with EA present at approximately three times the concentration of transVA $(28.1 \% \pm 3.6$ versus $9.5 \% \pm 1.1$ ). In humans, transVA is desaturated into CLA with a conversion rate estimated to be $19 \%$ [35]. We observed $2.47 \% \pm 0.16 \mathrm{CLA}$, when supplementing with transVA, corresponding to $21 \%$ of the combined transVA and CLA (Fig. 2b), thus reflecting the estimated human conversion rate. Palmitic acid is the measured non-supplemented fatty acid that differed the most in amount between experimental groups, and is lower when cells were supplemented with EA and OA than compared to both supplementation with transVA or cisVA $(p<0.05)$ and the largest difference is observed between transVA and EA supplementation. In conclusion, HepG2-SF cells take up and metabolize all the supplemented fatty acids. However, after 7 days of supplementation, the measured amounts of EA and transVA isomers in TG differed between experimental groups, indicating a differential lipid metabolic response to the TFA isomers.

\section{Identification and quantitation of proteins differentially regulated by transVA, EA and cisVA using SILAC}

SILAC was applied to investigate the cellular proteomic response of the predominant rTFA and iTFA, transVA and EA respectively, and compare their response to the cisVA Both the secreted and the intracellular proteins were investigated. A total of 3074 proteins were identified and of these 538 were quantifiable across all three groups. In the trans-trans comparison EA/VA 25 proteins were significantly regulated with a fold $>1.3$. In the trans-cis comparison transVA/cisVA 20 proteins were significantly regulated with a fold $>1.3$, and in EA/cisVA 24 proteins were significantly regulated with fold $>1.3$. A total of 47 differentially regulated proteins were found $(p<0.01$, fold $>1.3$, Table 1 and Additional file 2: Data S2). Functional clustering analysis showed that the most significant functions represented by the regulated proteins were lipid and cholesterol metabolic processes including specifically cholesterol biosynthetic process. Except for apoA1, the regulated proteins involved in cholesterol synthesis are specifically up-regulated by EA and not trans $\mathrm{VA}$, demonstrating that this response is isomer specific. Eight of the 17 proteins categorized in lipid metabolism process are up-regulated by EA when compared to both transVA and cisVA and only 3 nonlipid metabolism proteins (tricarboxylate transport protein-mitochondrial, membrane-associated progesterone receptor component 1 , and filamin-B) are regulated in these comparisons. 

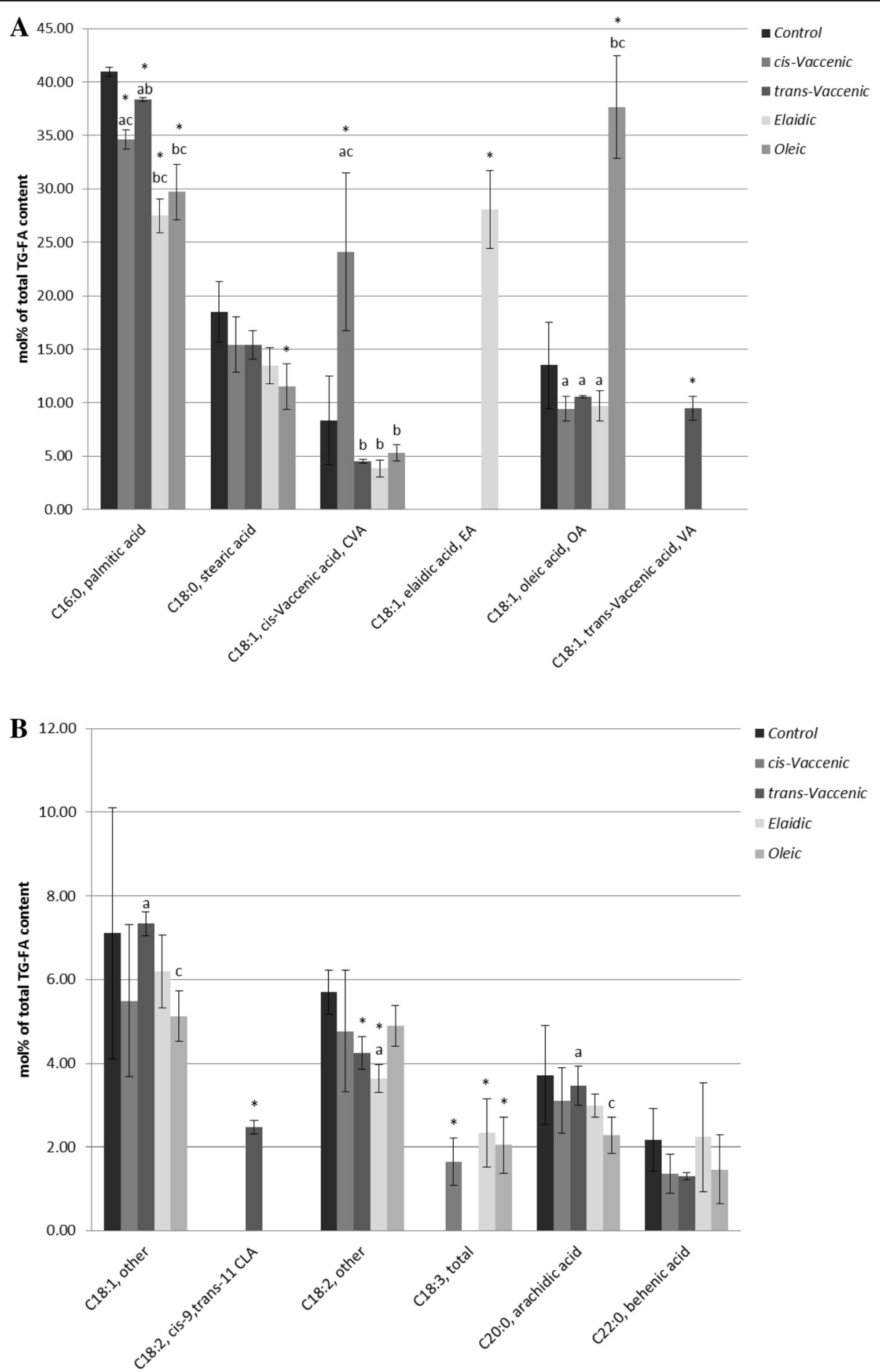

Fig. 2 The fatty acid composition of HepG2-SF TG after fatty acid supplementation. HepG2-SF TG composition was analyzed by gas liquid chromatography after 7 days incubation in fatty acid supplemented medium (100 $\mu \mathrm{M})$. Panel $\mathbf{a}$ and $\mathbf{b}$ are high and low abundant fatty acids present in the TG, respectively. Content of individual fatty acids ( $x$-axis), analyzed as extracted FAME, are averaged over three biological replicas and displayed as \% of total TG derived FAME measured (y-axis). The supplemented TFAs esterify at different levels into HepG2-SF TG and EA is found at approximately three times the level of transVA. The analysis shows that the supplemented fatty acids are taken up and metabolized by HepG2-SF cells. In addition, it demonstrates that EA is accumulating in TG when compared to the other experimental groups. *significantly different from Control at $p<0.05$. Fatty acids significantly differing between experimental groups at $p<0.05$ are marked with: a) different from $\mathrm{OA}$, b) different from cisVA and c) different from transVA 
Table 1 Differentially regulated proteins between trans-Vaccenic, cis-Vaccenic and Elaidic revealed by SILAC

\begin{tabular}{|c|c|c|c|c|c|c|c|c|}
\hline \multirow{2}{*}{$\begin{array}{l}\text { Uniprot } \\
\text { accession } \\
\text { no. }\end{array}$} & \multirow[b]{2}{*}{ Name } & \multicolumn{2}{|c|}{ EA/transVA } & \multicolumn{2}{|c|}{ EA/cis VA } & \multicolumn{2}{|c|}{$\operatorname{trans\mathrm {VA}/cis\mathrm {VA}}$} & \multirow[b]{2}{*}{ selected GO-terms ${ }^{b)}$} \\
\hline & & Fold $^{\text {a) }}$ & $\begin{array}{l}\text { Geo. } \\
\text { SD. }\end{array}$ & Fold & $\begin{array}{l}\text { Geo. } \\
\text { SD. }\end{array}$ & Fold & $\begin{array}{l}\text { Geo. } \\
\text { SD. }\end{array}$ & \\
\hline \multicolumn{9}{|c|}{ Extracellular } \\
\hline P02647 & Apolipoprotein A-I & 1.20 & 1.10 & -1.08 & 1.06 & -1.31 & 1.11 & $a, b, c$ \\
\hline P06727 & Apolipoprotein A-IV & 1.49 & 1.09 & 1.44 & 1.09 & -1.04 & 1.08 & $\mathrm{~b}, \mathrm{c}$ \\
\hline Q8NBP7 & Proprotein convertase subtilisin/kexin type 9 & 2.01 & 1.14 & 1.73 & 1.11 & -1.18 & 1.07 & $b, c$ \\
\hline P10909 & Clusterin & -1.46 & 3.17 & 1.42 & 1.09 & 1.27 & 1.20 & $\mathrm{c}$ \\
\hline P08185 & Corticosteroid-binding globulin & 1.71 & 1.14 & 1.16 & 1.16 & -1.53 & 1.09 & $\mathrm{c}$ \\
\hline Q99969 & Retinoic acid receptor responder protein 2 & 1.31 & 1.11 & 1.08 & 1.03 & -1.23 & 1.14 & $\mathrm{c}$ \\
\hline P02753 & Retinol-binding protein 4 & 1.09 & 1.13 & -1.13 & 1.11 & -1.34 & 1.06 & $\mathrm{c}$ \\
\hline P25311 & Zinc-alpha-2-glycoprotein & -1.62 & 7.14 & & & 1.93 & 1.04 & c \\
\hline P02765 & Alpha-2-HS-glycoprotein & 1.05 & 1.17 & -1.32 & 1.17 & -1.38 & 1.07 & \\
\hline P27487 & Dipeptidyl peptidase 4 & 1.23 & 1.09 & 1.43 & 1.16 & 1.20 & 1.19 & \\
\hline P02671 & Fibrinogen alpha chain & 1.55 & 1.10 & -1.08 & 1.08 & -1.73 & 1.14 & \\
\hline P51654 & Glypican-3 & 1.25 & 1.10 & -1.03 & 1.20 & -1.35 & 1.15 & \\
\hline P05546 & Heparin cofactor 2 & 1.59 & 1.08 & 1.03 & 1.11 & -1.57 & 1.16 & \\
\hline P08833 & Insulin-like growth factor-binding protein 1 & -1.53 & 1.06 & -2.21 & 1.08 & -1.48 & 1.07 & \\
\hline P61626 & Lysozyme C & 1.33 & 1.03 & 1.05 & 1.08 & -1.26 & 1.06 & \\
\hline Q16819 & Meprin A subunit alpha & 1.07 & 1.06 & -1.23 & 1.07 & -1.37 & 1.06 & \\
\hline P01033 & Metalloproteinase inhibitor 1 & -1.13 & 1.07 & -1.42 & 1.08 & -1.27 & 1.07 & \\
\hline P36955 & Pigment epithelium-derived factor & 1.23 & 1.05 & -1.02 & 1.05 & -1.30 & 1.07 & \\
\hline P05154 & Plasma serine protease inhibitor & 1.17 & 1.05 & -1.14 & 1.06 & -1.38 & 1.08 & \\
\hline P05121 & Plasminogen activator inhibitor 1 & -1.08 & 1.12 & -1.39 & 1.08 & -1.35 & 1.11 & \\
\hline P02787 & Serotransferrin & -5.34 & 1.89 & 1.31 & 1.11 & 7.25 & 2.02 & \\
\hline P35542 & Serum amyloid A-4 protein & 1.33 & 1.14 & 1.07 & 7.09 & -1.27 & 1.13 & \\
\hline O76061 & Stanniocalcin-2 & -1.24 & 1.25 & -1.45 & 1.10 & -1.20 & 1.16 & \\
\hline P10646 & Tissue factor pathway inhibitor & 1.15 & 1.09 & -1.15 & 1.15 & -1.33 & 1.13 & \\
\hline P02766 & Transthyretin & -1.91 & 1.39 & 1.97 & 1.06 & 3.47 & 1.33 & \\
\hline \multicolumn{9}{|c|}{ Intracellular } \\
\hline Q9UBM7 & 7-dehydrocholesterol reductase & 1.83 & 7.07 & 1.73 & 1.02 & & & $a, b, c$ \\
\hline P14324 & Farnesyl pyrophosphate synthase & 1.47 & 1.05 & 1.60 & 1.10 & 1.07 & 1.07 & $\mathrm{a}, \mathrm{b}, \mathrm{c}$ \\
\hline Q13907 & Isopentenyl-diphosphate Delta-isomerase 1 & 1.31 & 1.04 & 1.40 & 1.06 & 1.06 & 1.02 & $a, b, c$ \\
\hline P37268 & Squalene synthase & 1.81 & 1.05 & 1.86 & 1.09 & 1.01 & 1.02 & $a, b, c$ \\
\hline Q15738 & $\begin{array}{l}\begin{array}{l}\text { Sterol-4-alpha-carboxylate 3-dehydrogenase, } \\
\text { decarboxylating }\end{array} \\
\end{array}$ & 1.55 & 1.08 & 1.37 & 1.10 & -1.17 & 7.14 & $\mathrm{a}, \mathrm{b}, \mathrm{c}$ \\
\hline Q9BWD1 & Acetyl-CoA acetyltransferase, cytosolic & 1.46 & 1.14 & 1.51 & 1.09 & 1.08 & 1.10 & $\mathrm{c}$ \\
\hline Q86TX2 & Acyl-coenzyme A thioesterase 1 & 1.32 & 1.06 & 1.26 & 1.16 & -1.06 & 1.11 & \begin{tabular}{|l}
$\mathrm{c}$ \\
$\mathrm{c}$
\end{tabular} \\
\hline P53396 & ATP-citrate synthase & 1.69 & 1.09 & 1.86 & 1.08 & 1.11 & 1.20 & $\mathrm{c}$ \\
\hline Q9H6R3 & $\begin{array}{l}\text { Acyl-CoA synthetase short-chain family } \\
\text { member 3, mitochondrial }\end{array}$ & 1.38 & 1.01 & 1.38 & 1.03 & & & \\
\hline P07858 & Cathepsin B & 1.25 & 1.05 & -1.09 & 1.07 & -1.36 & 1.09 & \\
\hline P02792 & Ferritin light chain & -1.57 & 1.18 & 1.30 & 1.15 & 2.06 & 1.22 & \\
\hline O75369 & Filamin-B & 1.34 & 1.08 & 1.42 & 1.10 & 1.06 & 1.05 & \\
\hline P04792 & Heat shock protein beta-1 & 1.1528 & 81.01 & 1.39 & 1.08 & 1.19 & 1.07 & \\
\hline P10619 & Lysosomal protective protein & -1.22 & 1.07 & 1.28 & 1.02 & 1.52 & 1.05 & \\
\hline O00264 & $\begin{array}{l}\text { Membrane-associated progesterone receptor } \\
\text { component } 1\end{array}$ & 1.45 & 1.10 & 1.62 & 1.08 & 1.00 & 1.07 & \\
\hline P17987 & T-complex protein 1 subunit alpha & -1.30 & 1.18 & -1.12 & 1.06 & 1.06 & 1.08 & \\
\hline Q16881 & Thioredoxin reductase 1 , cytoplasmic & -1.28 & 1.06 & 1.01 & 1.04 & 1.31 & 1.10 & \\
\hline P53007 & Tricarboxylate transport protein, mitochondrial & 1.52 & 1.15 & 1.50 & 1.13 & -1.03 & 1.05 & \\
\hline P06753 & Tropomyosin alpha-3 chain & 1.02 & 1.07 & 1.33 & 1.03 & 1.29 & 1.06 & \\
\hline P67936 & Tropomyosin alpha-4 chain & 1.06 & 1.02 & 1.35 & 1.03 & & & \\
\hline P23381 & \begin{tabular}{|l|} 
Tryptophan--tRNA ligase, cytoplasmic \\
\end{tabular} & -1.55 & 1.03 & -1.32 & 1.12 & 1.16 & 1.09 & \\
\hline P62979 & Ubiquitin-40S ribosomal protein S27a & -1.30 & 1.08 & -1.23 & 1.24 & -1.07 & 1.39 & \\
\hline
\end{tabular}

Proteins are reported with Uniprot accession number, Name, Fold regulation in individual comparisons, the geometric standard deviation (Geo.SD.) and selected GO-terms

a) black bold: significant regulatory data $(p<0.01)$ with fold $>1.3$, black italic: significant regulatory data $(p<0.01)$ with fold $<1.3$, grey italic: not significant regulatory data $(p>0.01)$

b) a: cholesterol biosynthetic process (GO:0006695), b: cholesterol metabolic process (GO:0008203), and c: lipid metabolic process (GO:0006629) 
Corticosteroid binding protein, classified in lipid metabolism, was down-regulated upon transVA-supplementation in both transVA/EA and transVA/cisVA. Heparin cofactor 2 and fibrinogen alpha chain are non-lipid metabolism proteins regulated by transVA-supplementation. They were both down-regulated. Three proteins were down-regulated by both TFAs when compared to cisVA, these were plasminogen activator inhibitor 1 (PAI1), alpha-2-HS-glycoprotein (AHSG) and insulin-like growth factor-binding protein 1 (IGFBP1). Transthyretin (TTR) is up-regulated in both trans VA/cisVA and EA/cisVA.

The SILAC analysis showed that the overlap of differentially regulated proteins between the comparisons EA/ cis $\mathrm{VA}$ and transVA/cisVA is rather small, comprising $16 \%$ and $20 \%$, respectively, of regulated proteins at fold $>1.3$, $p<0.01$. This suggests that cellular responses to the two major dietary TFAs are rather different. However, a shared TFA-induced response was observed for PAI1, AHSG, IGFBP1, and TTR, as mentioned above.

\section{Identification and quantitation of secreted proteins differentially regulated by transVA, EA and cisVA using DIGE}

To further investigate the effects of TFA isomers on plasma protein levels and to gain more information on differentially regulated secreted proteins, the experimental medium from fatty acid supplementations of HepG2SF cells were analyzed by DIGE. Approximately 2000 spots were detected per gel and 1000 aligned across all analytical gels. Using the criteria of 1.3 fold regulation at $p$-value $<0.05$ the numbers of differentially regulated spots were 44 in EA/transVA and 5 in transVA/cisVA. From the 44 differentially regulated spots in the transtrans comparison EA/transVA, 12 unique proteins (excl. human serum albumin) were identified, and from the 5 differentially regulated spots in the trans-cis comparison trans $\mathrm{VA} /$ cis $\mathrm{VA}, 3$ unique proteins were identified (Table 2 and Additional file 3: Data S3). EA, compared to transVA, induced up-regulation of apoA1 and apoE, which are apolipoproteins of HDL and VLDL respectively, and downregulation of AHSG, which inversely correlate with CVD risk [36] and is suggested as a biomarker for TFA intake [37]. ApoA4 was up-regulated in both EA/transVA and transVA/cisVA. Four spots, upregulated by transVA when compared to EA, were identified as complement C3 with migration in the $2 \mathrm{D}$ gel estimated at a pI a little below 5 and a mass of approximately $40 \mathrm{kDa}$ (Table 2, Additional file 3: data S3 and Additional file 4: Figure S1). The peptides, derived from the spots and identifying the proteins as complement C3, all locate in the c-terminal part of C3 corresponding to the $\mathrm{C} 3 \mathrm{c}$ alpha' chain fragment 2 . This also fits the mass and pI observed, thus indicates increased complement C3 activation by transVA. The DIGE results thus support and supplement the SILAC results, as will be discussed, which further underline the indication that the major iTFA (EA) and the major rTFA (transVA) promote relatively different hepatocellular responses.

\section{Identification and quantitation of proteins differentially regulated by transVA, OA and CLA using SILAC}

$\mathrm{OA}$ is the most abundant of naturally occurring C18:1 cis fatty acids in food stuff, and it was included in a separate SILAC analysis comparing OA-supplemented cells to trans $\mathrm{VA}$, to test if the trans $\mathrm{VA}$ induced response, observed in the transVA-cisVA-EA comparison described above, could also be confirmed with reference to OA. CLA was included in this second SILAC setup, as mammalian cells are able to further desaturate transVA to yield CLA. The cellular response to $100 \mu \mathrm{M}$ CLA was investigated to assess if the transVA to CLA conversion contributes to the observed trans VA response.

A total of 3191 proteins were identified in this second SILAC triplex setup and of these 15 were differentially regulated in the transVA/OA comparison within the fold 1.3 criteria set, $p<0.01$. For CLA/transVA and CLA/OA the numbers were 26 and 39, respectively (Additional file 5: Data S4). Five of the 15 proteins significantly regulated in transVA/OA were also regulated in the first SILAC transVA-cisVA-EA triplex. The down-regulation of AHSG, fibrinogen alpha chain and corticosteroid binding globulin was confirmed in transVA/OA together with downregulation of glypican 3 and stanniocalcin 2 .

If the cellular response to transVA was in part mediated by its conversion to CLA, supplementation with $100 \mu \mathrm{M}$ CLA would be expected to enhance the response observed during supplementation with transVA. Ten of the 26 proteins significantly regulated in the CLA/ transVA comparison were also regulated in the first SILAC transVA-cisVA-EA triplex. Eight of these were in CLA/VA regulated in the opposite direction as in the transVA/cisVA comparison. This demonstrates that the trans $\mathrm{VA}$ induced response is not significantly contributed by the presence of CLA, and furthermore the data suggests that the cis-desaturation on the $\Delta 9$ position in CLA may neutralize some of the effects of the $\Delta 11$ trans-double bond.

\section{Discussion}

Investigations of adverse health effects related to TFA intake have not focused on the contribution of the individual positional TFA isomers. We have in earlier studies investigated the differential response of human hepatocytes, HepG2-SF, to the two geometric $\Delta^{9} \mathrm{C} 18: 1$ isomers OA (cis $\left.\Delta^{9} \mathrm{C} 18: 1\right)$ and EA (trans $\left.\Delta^{9} \mathrm{C} 18: 1\right)$. The studies revealed substantial differences in abundance of proteins involved in cholesterol synthesis and lipid metabolism in general and furthermore indicated remodeling of the phospholipids caused by the EA supplementation of the 
Table 2 Differentially regulated secreted proteins revealed by DIGE and identified by mass spectrometry

\begin{tabular}{|c|c|c|c|c|c|c|}
\hline \multirow[b]{2}{*}{ Protein name } & \multirow[b]{2}{*}{ Uniprot name } & \multirow[b]{2}{*}{ spot no } & \multicolumn{2}{|c|}{ EA/transVA } & \multicolumn{2}{|c|}{ transVA/cisVA } \\
\hline & & & Av. Ratio & $p$-value & Av. Ratio & $p$-value \\
\hline 14-3-3 protein zeta/delta & 1433Z/P63104 & 2180 & & & -1.43 & $3.0 \mathrm{E}-02$ \\
\hline Aldose 1-epimerase & GALM/Q96C23 & 1832 & 2 & $2.5 \mathrm{E}-03$ & & \\
\hline Alpha-1-antitrypsin & A1AT/P01009 & 1330 & 1.79 & 3.6E-04 & & \\
\hline Alpha-1-antitrypsin & & 1342 & 1.96 & $3.9 \mathrm{E}-03$ & & \\
\hline Alpha-2-HS-glycoprotein & FETUA/P02765 & 1400 & -1.51 & $3.4 \mathrm{E}-02$ & & \\
\hline Apolipoprotein A1 & APOA1/P02647 & 2333 & 1.57 & $2.0 \mathrm{E}-04$ & & \\
\hline Apolipoprotein A4 & APOA4/P06727 & 1737 & 1.57 & 7.3E-03 & 1.39 & $4.8 \mathrm{E}-02$ \\
\hline Apolipoprotein A4 & & 1741 & 1.7 & 1.7E-04 & 1.4 & $2.8 \mathrm{E}-03$ \\
\hline Apolipoprotein A4 & & 1743 & 1.43 & 2.3E-02 & & \\
\hline Apolipoprotein E & APOE/P02649 & 2030 & 1.39 & $5.9 \mathrm{E}-03$ & & \\
\hline Carboxypeptidase E & CBPE/P16870 & 1417 & -1.78 & $1.3 \mathrm{E}-03$ & & \\
\hline Chloride intracellular channel protein1 & CLIC1/000299 & 2106 & 1.75 & $1.9 \mathrm{E}-03$ & & \\
\hline Complement C3 & CO3/P01024 & 1675 & -1.41 & 3.1E-02 & & \\
\hline Complement C3 & & 1706 & -1.51 & 4.6E-03 & & \\
\hline Complement C3 & & 1708 & -1.51 & 4.6E-03 & & \\
\hline Complement C3 & & 1710 & -1.51 & $8.8 \mathrm{E}-04$ & & \\
\hline Complement factor B & CFAB/P00751 & 726 & -1.32 & $2.5 \mathrm{E}-03$ & & \\
\hline Endoplasmin & ENPL/P14625 & 737 & -1.51 & 4.8E-02 & & \\
\hline Proteasome subunit alpha type- 5 & PSA5/P28066 & 2203 & & & -1.37 & 4.7E-02 \\
\hline Protein AMBP & AMBP/P02760 & 2042 & 1.62 & $2.2 \mathrm{E}-03$ & & \\
\hline Serotransferrin & TRFE/P02787 & 1005 & 1.56 & $8.0 \mathrm{E}-04$ & & \\
\hline Serotransferrin & & 1007 & 2.02 & 2.7E-04 & & \\
\hline Serotransferrin & & 1033 & 1.65 & $1.5 \mathrm{E}-04$ & & \\
\hline Serotransferrin & & 1765 & 1.43 & 1.1. $\mathrm{E}-02$ & & \\
\hline
\end{tabular}

The secretome of hepatocytes supplemented with transVA, EA, or cisVA were analyzed by DIGE and subsequently the regulated proteins were identified by LCMS/MS analyses. In the table proteins are reported with protein name, Uniprot name/accession number, 2D gel spot number (spot no), Average ratio (Av.ratio), and $p$-value for individual comparisons

cells $[37,38]$. In the present study, we investigate if the hepatocellular responses to the two most abundant positional C18:1 TFA isomers in the human diet, EA and transVA, are comparable. The cisVA was included to test if also the $\Delta^{11} \mathrm{C} 18: 1$ geometrical isomers showed the same affect on HepG2-SF cells, as previously shown for the $\Delta^{9} \mathrm{C} 18: 1$ geometrical isomers.

\section{Supplemented trans fatty acids esterify at different amounts into the TG of liver cells}

To our knowledge, TFA induced hepatic responses have not earlier been investigated in human cell cultures, although a study using rat hepatocytes showed that short-term ( $2 \mathrm{~h}$ ) exposure to EA or transVA causes equal incorporation of the TFAs into TG [39]. Contrary to the results in rats, we showed, by the analyses of FAME derived from HepG2-SF TG, that after 7 days supplementation with EA or transVA that the TG fraction contained more than double the amount of EA to that of transVA. Upon supplementation, transVA and cisVA esterified to similar extend into the TG fraction. TG acts as a cellular storage site for fatty acids, which can be used for energy production through $\beta$-oxidation in mitochondria and peroxisomes. In rat the $\beta$-oxidation rate of EA has been shown to be $30 \%$ lower than for both transVA and cis VA [40] because a $\beta$-oxidation intermediate of EA slows $\beta$-oxidation progress [41]. If this occurs in human cells, EA may thus be accumulating in TG as $\beta$-oxidation slows down and this may be the reason for our observation of different relative amounts of TFAs in HepG2-SF TG. However, the total amounts of TG per cell in each experimental group were not determined in the present study. Consequently, it cannot be concluded if EA-containing TGs are added to the TG pool or if EA substitutes for other fatty acids, for example palmitic acid, keeping total TG at a constant amount. 


\section{EA and transVA affect lipid metabolism-related proteins differently}

The cellular proteomic responses to EA, transVA and cisVA were analyzed using SILAC and DIGE. The SILAC analysis identified 47 differentially regulated proteins in $\mathrm{EA} /$ trans $\mathrm{VA}$, transVA/cisVA and/or EA/cisVA (Table 1) and functional cluster analysis showed that the main perturbed cellular functions are lipid and cholesterol metabolism. In a previous study, comparing the HepG2-SF responses to EA and OA, we found that the major part of proteins associated with cholesterol synthesis were upregulated in the TFA treated cells [38]. Moreover, in rat hepatocytes EA supplementation caused an increased cholesterol efflux as compared to both transVA and cisVA [39]. In the present study, we find several of the proteins involved in lipid metabolism, and especially cholesterol synthesis, to be up-regulated by EA, when compared to both transVA and cisVA. It supports the findings in rats and suggests that the increased cholesterol efflux is in part a result of increased synthesis. Also, Proprotein convertase subtilisin/kexin type 9 (PCSK9) was up-regulated in both $\mathrm{EA} /$ trans $\mathrm{VA}$ and $\mathrm{EA} /$ cis VA but unchanged in transVA/ cisVA. This protein can cause degradation of LDLreceptor [42] and thereby possibly decrease the LDLcholesterol uptake by the cell contributing to extracellular cholesterol accumulation. DIGE was performed on the secreted proteins from HepG2-SF cells, because it has been suggested that TFA may influence CVD risk by altering secretion of plasma proteins from the liver. Our DIGE data shows that apoA1, which is the major apolipoprotein of HDL, is up-regulated by EA when compared to transVA and unchanged in transVA/cisVA (Table 2). In SILAC the regulatory data for apoA1 is 1.2 fold for EA/ VA and -1.3 fold for transVA/cisVA. Cholesteryl ester transfer protein is responsible for cholesteryl ester transfer from HDL to LDL and its activity is increased by TFA [43]. If ApoA1 is up-regulated by EA, this may cause an increased extracellular capacity for cholesterol, and with increased CETP activity this may aid cholesterol accumulation in LDL.

\section{Trans fatty acid specific responses}

The SILAC analysis revealed four proteins that were significantly regulated in the same direction, but not necessarily to the same extent, by both TFAs when compared to cisVA. These included TTR, which is up-regulated, and PAI1, IGFBP1 and AHSG, which are down-regulated. We have in a previous biomarker study compared EA with $\mathrm{OA}$ and among other candidates found TTR, PAI1, IGFBP1 and AHSG as potential biomarkers for TFAintake [37]. The present study supports that the regulation of these proteins are TFA specific. Decreased level of metalloproteinase inhibitor 1 (TIMP1) was also suggested as a potential biomarker for EA intake [37], and this protein was down-regulated in EA/cisVA (-1.42) and just below the fold cut-off in transVA/cisVA (-1.27), also indicating this to be a TFA-specific response.

In the previous biomarker study PCSK9, ApoA4, tissue factor pathway inhibitor (TFPI), AHSG, and serotransferrin were also shown to be potential biomarkers for EA supplementation, when compared to OA [37]. PCSK9, ApoA4 and serotransferrin were up-regulated, TFPI and AHSG down-regulated. In the present investigations, SILAC analysis confirmed that PCSK9 and ApoA4 were up-regulated and potential EA biomarkers. TFPI was down-regulated by transVA when compared to cis-VA $(-1.33)$, and the fold down-regulation in EA/cisVA was 1.15. Serotransferrin was up-regulated in EA/cisVA (1.31), but lacked significance in regulation in the other comparisons. In the DIGE characterization of the proteins secreted by HepG2-SF cells, ApoA4 and serotransferrin were up-regulated (on average 1.57 and 1.67, respectively) and AHSG down-regulated $(-1.51)$ in the EA/VA comparison (Table 2), confirming the observed changes in the EA/OA comparison [37] underlining that these are potential biomarkers for EA intake. However, ApoA4 was also up-regulated in the DIGE transVA/cisVA comparison (1.4), which shows that this response is not EA-specific though more pronounced by EA than by transVA supplementation. Noteworthy, all the regulated and discussed proteins (PCSK9, AHSG, ApoA4, TIMP1, TFPI, PAI1 and IGFBP1) have previously been mentioned in the context of CVD risk [36, 37, 44-47].

However, 18 of the 26 proteins differentially regulated in CLA/transVA categorize with the GO-term: Response to stress, all up-regulated by CLA, and seven of these are part of the acute inflammatory response. This may indicate that the high concentration of CLA is stressful or even toxic for HepG2-SF cells, though not decreasing viability after a seven days period. A blood concentration of $100 \mu \mathrm{M}$ CLA is not easily reached through diet, and though interesting it is beyond the scope of this paper to further discuss the cellular response to CLA.

\section{The complement system is affected by TFA}

Artherosclerosis is considered an inflammatory condition [48]. It has been suggested that dietary TFA induces vascular inflammation and effects on several markers of endothelial cell dysfunction and inflammatory responses have been documented [24, 49, 50]. Though a TFA, transVA did not induce this effect in endothelial cells and may even protect against vascular inflammation measured as decreased T-helper cell cytokine production [24, 25]. Part of the vascular inflammatory response is the activation of the complement system, and a key protein is complement factor $\mathrm{C} 3$ (CO3). Blood $\mathrm{CO} 3$ is a predictor of myocardial infarction [51] and correlates positively with obesity and coronary artery disease [52]. In the DIGE 
study we identify $\mathrm{CO} 3$ in 4 spots, up-regulated by transVA when compared to EA and unchanged when compared to cisVA (Table 2, Additional file 3: Data S3 and Additional file 4: Figure S1). These spots correspond to the most Cterminal part of $\mathrm{CO} 3$, the $\mathrm{C} 3 \mathrm{c}$ alpha chain fragment 2 . By SILAC it is observed that the overall $\mathrm{CO} 3$ level is significantly increased by EA compared to transVA (1.27 fold), and up-regulation in cisVA/VA is also indicated (Additional file 2: Data S2). The regulatory data for $\mathrm{CO} 3$ suggests that supplementation with transVA gives the lowest overall level of $\mathrm{CO} 3$, but the highest level of $\mathrm{CO} 3$ activation relative to total amount. Complement factor $\mathrm{B}$ is also an important protein in the complement system, which upon binding to $\mathrm{CO} 3 \mathrm{~b}$ fragment interacts with and activates complement factor $\mathrm{D}$, which in turn cleaves factor B [53]. The cleaved form of factor B forms a complex with the $\mathrm{CO} 3 \mathrm{~b}$ fragment in the formation of $\mathrm{C} 3$ convertase, which further accelerate the cleavage of $\mathrm{CO} 3$. Complement factor B was significantly up-regulated 1.2 fold in SILAC in both EA/VA and cisVA/transVA i.e. down-regulated by transVA (Additional file 2: Data S2). In DIGE judging by mass, pI, spot pattern, and identification by MS/MS, the full-length complement factor B was observed as a train of spots, with one spot up-regulated 1.42 fold and another down-regulated 1.32 fold in EA/VA. This observation in DIGE suggests a change in the glycosylation pattern, with an EA induced deglycosylation of factor B. Deglycosylation at Asn260 of factor B causes increased affinity for the $\mathrm{CO} 3 \mathrm{~b}$ fragment [54] and deglycosylation at Asn353 is suggested to increase cleavage by factor D and thus deglycosylation at both sites can increase formation of the C3 convertase [55]. Whether the observed change in spot pattern on our 2D gels is due to deglycosylation at either of the mentioned sites, with implication for complement activation due to $\mathrm{EA}$, requires further investigations.

Some proteins categorized in the acute inflammatory/ acute phase response are also regulated by the TFAs investigated, though not clearly confirming or rejecting an acute phase response. These include the positive acute phase proteins: fibrinogen alpha chain (SILAC: EA/VA 1.55 fold, transVA/cisVA -1.73 fold), PAI1 (SILAC: EA/ cis VA -1.39, trans VA/cis VA -1.35), serum amyloid A-4 (SILAC: EA/transVA 1.33, transVA/cisVA -1.27) and ferritin light chain (SILAC: EA/transVA -1.57, transVA/ cisVA 2.06), and the negative acute phase proteins: AHSG (SILAC: EA/cisVA -1.32, transVA/cisVA -1.38; DIGE EA/ VA -1.51), serotransferrin (SILAC: EA/cisVA 1.31; DIGE EA/transVA 1.67) and TTR (SILAC: EA/cisVA 1.97, transVA/cisVA 3.47).

\section{Regulators of blood coagulation are affected by TFA}

By SILAC fibrinogen alpha chain was the only protein to be significantly regulated specifically by transVA when compared to both EA and cisVA $(-1.55$ and -1.73 fold regulation, respectively). Though not significant at $p<0.01$ both fibrinogen beta and gamma chain also showed approximately 1.6 fold down-regulation by transVA supplementation (Additional file 2: Data S2). PAI1 was decreased by both EA and transVA. Increased plasma fibrinogen and PAI1 levels correlates with increased thrombosis risk $[44,56]$, and thus transVA may have a potential beneficial influence on the level of these proteins in regards of CVD risk. However, the observed decrease in level of fibrinogen could also indicate a transVA-induced shift towards coagulation of the equilibrium between coagulation and fibrinolysis, resulting in consumption of fibrinogen. The possibility of increased coagulation is supported by the observation that both TFPI and heparin cofactor 2 are also decreased by transVA-supplementation. TFPI is a major inhibitor of the extrinsic coagulation pathway through its interaction with Factor Xa and tissue factor-factor VIIa complex [57, 58], and heparin cofactor 2 inhibits thrombin action [59], thus low level of both may promote thrombophilia. Whether transVA promotes or protects against thrombophilia is thus difficult to conclude from the present experiments, however it clearly affects levels of regulators of blood coagulation.

\section{Conclusion}

It has previously been established that iTFAs correlate with CVD risk [3]. However, a diet very high in rTFA also negatively affects CVD risk factors [20]. It has therefore previously been discussed if transVA and EA in food have different effects on human health, or whether it is merely a matter of the total dietary TFA amount consumed [60]. Our study shows that partially differential hepatocellular responses to the two C18:1 TFA isomers transVA and EA occurs. EA specifically induces an increase in proteins involved in cholesterol synthesis and cholesterol transport, a response not shared with transVA. The results of this investigation suggest that EA has an adverse effect on cholesterol metabolism that could be unique to the main TFA isomers found in foodstuff and explain its stronger correlation with CVD risk than for transVA, but this requires more investigations in animal models and ultimately in clinical intervention studies.

\section{Methods \\ Materials}

Cis-vaccenic acid (>97 \% purity) and Conjugated linoleic acid ( $>96 \%$ purity) were purchased from Cayman Chemicals. ${ }^{13} \mathrm{C}_{6}$ Arginine and ${ }^{13} \mathrm{C}_{6}^{15} \mathrm{~N}_{4}$ Arginine (both $99 \%$ purity) were from Cambridge isotope laboratories (Andover, MA, USA). Elaidic acid, Oleic acid, trans-vaccenic acid, LLysine and Arginine (all $99 \%$ purity), Anhydrous dimethyl formamid (99.5\% purity), iodoacetamide, tetra-methyl- 
ethylene-diamine, L-Glutamine, Human serum albumin and RPMI-1640 without Arginine, Lysine and Leucine were purchased from Sigma. Regular SynQ serum substitute and SynQ without Arginine and Lysine was from Cell Culture Service, Hamburg Germany. All reagents for DIGE were PlusOne quality from GE Healthcare. Also CyDye DIGE fluors, IPG running buffers and PD10 columns were purchased from GE Healthcare. Penicillin, Streptomycin, regular RPMI-1640 and CyQuant NF proliferation assay kit were from Invitrogen.

\section{Cell culture}

HepG2-SF cells (HepG2 cells optimized for serum free growth, Cell Culture Service, Hamburg, Germany) were propagated in $75 \mathrm{~cm}^{2}$ Nunc culture flasks in serum free medium composed of RPMI-1640, 10 \% SynQ Serum substitute (Contains: Oleic acid, $3.5 \mu \mathrm{M}$; Linoleic acid, $500 \mathrm{ng} / \mathrm{mL}$; Thioic acid, $250 \mathrm{ng} / \mathrm{mL}$ ), $4 \mathrm{mM} \mathrm{L}$-glutamine, $20 \mathrm{U} / \mathrm{mL}$ penicillin and $20 \mu \mathrm{g} / \mathrm{mL}$ streptomycin, which was changed every third day. Cells were maintained at $37^{\circ} \mathrm{C}$ in a $5 \% \mathrm{CO}_{2}$ humidified incubator and subcultured every two weeks. For preparation of fatty acid supplemented medium, fatty acid in a 2:1 molar complex with human serum albumin [61] was adjusted to a final concentration of $100 \mu \mathrm{M}$ in serum free medium.

\section{Assessment of HepG2-SF growth in fatty acid} supplemented medium by CyQuant proliferation assay In a 96 well (low fluorescence) microtiter-plate 5,500 cells were seeded per well and allowed to attach for $24 \mathrm{~h}$ before $300 \mu 100 \mu \mathrm{M}$ fatty acid supplemented regular medium was added ( 4 replicas for each experimental group). On day $0,3,5$ and 7 after addition of supplemented media proliferation was assessed by adding $100 \mu \mathrm{l}$ CyQuant dye solution per well, and after $30 \mathrm{~min}$ incubation at $37{ }^{\circ} \mathrm{C}$ fluorescence was measured using a FLUOstar Omega (BMG Labtech) until a plateau was reached (excitation $480 \mathrm{~nm}, 520 \mathrm{~nm}$ emission, $3 \mathrm{~h}$ ). For comparison of experimental groups with Control equality of variance were tested (F-test) and appropriate two-tailed t-tests were performed.

\section{Measurement of fatty acids esterified into triacylglycerols (TG) by gas-liquid chromatography}

For each experimental group 3 replicas of three million cells each, incubated 7 days in fatty acid supplemented serum free medium as described above, were washed 2 times in sucrose buffer $(250 \mathrm{mM}$ sucrose, $50 \mathrm{mM} \mathrm{KCl}$, $2 \mathrm{mM} \mathrm{MgCl}_{2}, 20 \mathrm{mM}$ Tris-HCl, pH 7.6) and scraped off the petridish in $1 \mathrm{ml}$ sucrose buffer. Cells were centrifuged for $3 \mathrm{~min}$ at $180 \mathrm{~g}$ and the supernatant was discarded. Pellets were resuspended in methanol, vortexed and transferred to glass tubes with Teflon lined caps. Lipids were extracted with methyl-tert-butyl-ether according to [62] and subjected to thin layer chromatography on $20 \times 20$ $\mathrm{cm}$ silica gel 60 plates with glass backing (Merck) using a two-buffer system (buffer 1, 30 min: chloroform:methanol:acetic acid:water-50:30:8:3, buffer 2, 45 min: heptane:diethyl ether:acetic acid - 70:30:2). Plates were dried after the development and lipids were visualized by placing the plates in an iodine chamber, the TG bands were marked and scraped off the plate when iodine was evaporated. TG were extracted from silica with chloroform:methanol (2:1) and dried. Fatty acid methyl esters (FAME) were generated from the TG using $\mathrm{BF}_{3}$. First samples were mixed with $1 \mathrm{ml}$ methanolic $\mathrm{NaOH}(0.5 \mathrm{M})$ and heated for $5 \mathrm{~min}$ at $80{ }^{\circ} \mathrm{C}$. After cooling to room temperature $1 \mathrm{ml}$ of $\mathrm{BF}_{3}$ methanol (13-15\%) was added and again samples were heated at $80{ }^{\circ} \mathrm{C}$ for $2 \mathrm{~min}$ and cooled rapidly to room temperature. To improve FAME extraction to the organic phase, $0.2 \mathrm{ml}$ of a salt solution containing $\mathrm{NaCl}_{2}$ $(370 \mathrm{mg} / \mathrm{ml})$ and $\mathrm{K}_{2} \mathrm{CO}_{4}(1.5 \mathrm{mg} / \mathrm{ml})$ in water was added followed by $1 \mathrm{ml}$ of heptane. After $5 \mathrm{~min}$ centrifugation at $4000 \mathrm{rpm}$ the upper organic phase was isolated and dried over anhydrous $\mathrm{Na}_{2} \mathrm{SO}_{4}$ before application to gas-liquid chromatography. The FAME were analyzed on a Thermo Trace GC Ultra (Thermo Scientific, USA) equipped with auto-sampler, flame ionization detector and a Supelco SLB-IL100 column (60 m x 0.25 mm x $0.2 \mu \mathrm{m}$ film thickness, Sigma-Aldrich). Helium was used as a carrier gas with a flow rate of $1 \mathrm{ml} / \mathrm{min}$. An isothermal program at $180{ }^{\circ} \mathrm{C}$ for 25 min was applied. The injector and detector temperatures were set at $200{ }^{\circ} \mathrm{C}$ and $220{ }^{\circ} \mathrm{C}$, respectively. Five $\mu \mathrm{l}$ samples with a split flow of 10:1 were injected. Using Xcalibur software fatty acids were identified by comparing their retention times to standard mixtures and those eluting between $11.5 \mathrm{~min}$ and $23.5 \mathrm{~min}$ are expressed as mol \% based on an internal standard (methyl heptadecanoate).

Incubation of HepG2-SF cells in fatty acid supplemented media for Stable Isotope Labeling by Amino acids in Cell culture (SILAC)

Serum free medium was prepared from RPMI-1640 without Arginine, Lysine and Leucine and SynQ without Arginine and Lysine. The medium was then supplemented with Leucine and Lysine to a final concentration of $0.38 \mathrm{mM}$ and $1.02 \mathrm{mM}$, respectively. From this medium three different SILAC growth media were prepared containing $1.15 \mathrm{mM}$ Arginine, ${ }^{13} \mathrm{C}_{6}$ Arginine or ${ }^{13} \mathrm{C}_{6}^{15} \mathrm{~N}_{4}$ Arginine. To facilitate full incorporation of ${ }^{13} \mathrm{C}_{6}$ Arginine and ${ }^{13} \mathrm{C}_{6}^{15} \mathrm{~N}_{4}$ Arginine the cells were cultivated as described above for 5 population doublings with medium change every third day. The level of incorporation was tested by MALDI-MS prior to incubations with fatty acids in SILAC media. For preparation of fatty acid supplemented medium fatty acid in a 2:1 complex with human serum albumin [61] was adjusted to a final concentration of 
$100 \mu \mathrm{M}$ in SILAC serum free medium. Two SILAC triplex setups were made one using transVA (Arginine), EA $\left({ }^{13} \mathrm{C}_{6}\right.$ Arginine $)$ and cisVA $\left({ }^{13} \mathrm{C}_{6}^{15} \mathrm{~N}_{4}\right.$ Arginine), the other using transVA (Arginine), OA $\left({ }^{13} \mathrm{C}_{6}\right.$ Arginine) and CLA $\left({ }^{13} \mathrm{C}_{6}^{15} \mathrm{~N}_{4}\right.$ Arginine).

For each experimental group $75 \mathrm{~cm}^{2}$ culture flasks containing $90 \%$ confluent cells were trypsinized and seeded into four $6 \mathrm{~cm}$ petri dishes (= four replicas/experimental group). Cells were allowed to attach for $24 \mathrm{~h}$ before $3 \mathrm{~mL}$ fatty acid supplemented medium was added. The medium was changed on day two, four and six. On day 7 medium was aspirated and filtered (Sarstedt syringe filters, $0.22 \mu \mathrm{m}$ ) and kept on ice until further processing as described below. Cells were trypsinized, washed three times in cold PBS and lysed in lysis buffer (1 \% NP-40, $150 \mathrm{mM}$ $\mathrm{NaCl}, 50 \mathrm{mM}$ Tris, $0.1 \%$ SDS, $1 \mathrm{mM}$ PMSF, $25 \mu \mathrm{M}$ E64, $2 \mathrm{mM} 1.10$ Phenanthroline, $\mathrm{pH} 7,4)$ by sonication on ice. Lysate was centrifuged $\left(16000 \mathrm{~g}, 4{ }^{\circ} \mathrm{C}\right)$ and supernatant collected and kept on ice.

\section{SILAC sample preparation}

Cell medium was depleted for albumin by affinity chromatography on a column with a recombinant albumin binding domain from Streptococcal protein G [63]. The flow through was collected and the column regenerated using $20 \mathrm{mM} \mathrm{Na-citrate,} 150 \mathrm{mM} \mathrm{NaCl}, \mathrm{pH} 2.5$ before application of next sample. Between experimental groups the column was cleaned using $30 \%$ isopropanol, $2 \mathrm{M} \mathrm{NaCl}$. Protein concentration in depleted samples were determined using Bradford assay kit [64]. The 4 biological replicas in each group were pooled based on protein concentration and then the pools from different fatty acid incubations were mixed in a 1:1:1 ratio. The protein concentration in cell lysates were determined by 2D-Quant kit (GE Healthcare) and mixed as described for cell medium samples. Proteins from medium and lysates were separated in individual lanes by SDS-PAGE [65] and each lane was cut into bands. Proteins in the bands were in-gel digested using trypsin [66] and subsequently the resulting peptides were desalted on C18 stage tips (Proxeon).

\section{LC-MS/MS of SILAC samples}

The peptides were separated on an Easy-nLC II HPLC system (Thermo Scientific) equipped with a trap column (ReproSil-Pur C18-AQ $(5 \mu \mathrm{m}, 2 \mathrm{~cm} \times 100 \mu \mathrm{m}$ I.D., Thermo Scientific) and an analytical column (ReproSilPur C18-AQ column, $3 \mu \mathrm{m}, 10 \mathrm{~cm}$ x $75 \mu \mathrm{m}$ I.D., Thermo Scientific) in-line to a NanoSpray III source (AB Sciex) connected to a TripleTOF 5600 mass spectrometer (AB Sciex) operated under Analyst TF 1.5.1 control. Peptides were eluted at a constant flow of $250 \mathrm{nl} / \mathrm{min}$ with a 50 min gradient from 5 to $35 \%$ solvent B $(90 \% \mathrm{ACN}$, $0.1 \%$ formic acid) followed by re-equilibration for $10 \mathrm{~min}$ back to the starting conditions. Information dependent acquisition was employed acquiring up to $25 \mathrm{MS} / \mathrm{MS}$ spectra per cycle using $1.6 \mathrm{~s}$ cycle time with an exclusion window of $6 \mathrm{~s}$.

\section{SILAC data analysis}

All raw MS files were processed using Mascot Distiller 2.5.0 (Matrix Science). The MS data obtained by the analysis of gel lanes were merged into a multi-file-project using the default settings from the ABSciex_5600.opt file except that the MS/MS Peak Picking "Same as MS Peak Picking" was deselected and "Fit method" was set to "Single Peak". After peak picking all scans, the data were searched against Swiss-Prot Homo Sapiens database (v. 2013_11/12) using Mascot v. 2.3.02 (Matrix Science) [67]. The Search parameters allowed one missed trypsin cleavage site, propionamide as a fixed modification, and oxidation of methionine as a variable modification. The mass accuracy of the precursor and product ions were set to $10 \mathrm{ppm}$ and $0.2 \mathrm{Da}$, respectively, the instrument setting was specified as ESI-QUAD-TOF, and a significance threshold of 0.01 was used. The default SILAC R + $6 R+$ $10[\mathrm{MD}]$ quantitation protocol was selected using a significance threshold at 0.01 , matched rho was 0.7 , XIC threshold was 0.1 , isolated precursor threshold was set at 0.5 and normalization set to median. Mascot Distiller results were exported to $\mathrm{xml}$ files, imported into MS Data Miner v.1.2.0 (http://sourceforge.net/p/msdataminer [68]) and exported into Excel reports. Keratin was excluded as a general contaminant and a fold regulation threshold of 1.3 was selected for significant differentially regulated proteins. Spectra for differentially regulated proteins were manually inspected and proteins were excluded if not at least two unique peptides showed peaks for both light, medium and heavy label significantly above background (ion counts $>50$ ). The data are available via ProteomeXchange with identifier PXD000760 (http://proteomecentral.proteomexchange.org). Clustering analysis was done using the Functional Annotation tools of DAVID Bioinformatics Resources $6.7[69,70]$.

\section{Incubation of HepG2-SF cells in fatty acid supplemented media for DIGE}

Four $75 \mathrm{~cm}^{2}$ culture flasks containing $90 \%$ confluent cells were trypsinized and seeded into 16 new flasks (4 replicas/ group), and allowed to attach for two days before addition of fatty acid supplemented medium (10 ml/flask). Medium was changed on day 3 and 6 . On day 6 only $5 \mathrm{ml}$ fatty acid supplemented medium was added. The $5 \mathrm{ml}$ conditioned medium was collected on day 7, filtered, and stored on ice. Samples for DIGE was depleted for albumin as described for SILAC above and desalted using a PD10 column into $2.5 \mathrm{mM}$ Tris, $\mathrm{pH}$ 7.4. Aliquots of $50 \mu \mathrm{g}$ protein were dried in a SpeedVac and stored at $-20{ }^{\circ} \mathrm{C}$ until use. 
DIGE analysis of proteins secreted by HepG2-SF cells

A total of $50 \mu \mathrm{g}$ of protein was labeled using GE Healthcare CyDye DIGE Fluors (minimal dyes) according to the manufacturers instructions (GE Healthcare). The samples were labeled using 400 pmol Cy3 or Cy5 and as an internal standard, a pool of $25 \mu \mathrm{g}$ of each sample to be analyzed was labeled by 400 pmol Cy2 per $50 \mu$ g protein. Labeling was conducted in $7 \mathrm{M}$ Urea, $2 \mathrm{M}$ Thiourea, $4 \% \mathrm{w} / \mathrm{v}$ CHAPS, $10 \mathrm{mM}$ Tris, $\mathrm{pH}$ 8.5. After $30 \mathrm{~min}$ incubation the labeling reaction was quenched by adding $1 \mu \mathrm{l}$ $10 \mathrm{mM}$ lysine. Four experimental groups with 4 replicas were analyzed (two replicas in each group labeled with Cy3 and two with Cy5) resulting in a total of 8 analytical DIGE gels. The combination of samples differed in all gels and no gels contained two replicas from the same experimental group. Two samples labeled with $\mathrm{Cy} 3$ and $\mathrm{Cy} 5$ respectively were mixed with $50 \mu \mathrm{g}$ Cy2-labeled internal standard and volume adjusted to $130 \mu \mathrm{l}$ in rehydration solution (7 M Urea, $2 \mathrm{M}$ Thiourea, $4 \% \mathrm{w} / \mathrm{v}$ CHAPS, $0.5 \% \mathrm{v} / \mathrm{v}$ pH4-7 IPG carrier ampholytes, $40 \mathrm{mM}$ DTT, $10 \mathrm{mM}$ Tris, $\mathrm{pH}$ 8.5). The mixed samples were incubated in the dark, rotating at room temperature for $20 \mathrm{~min}$ and centrifuged $30 \mathrm{~min}$ at $16000 \mathrm{~g}$. Supernatants were subjected to isoelectric focusing by cup-loading on $24 \mathrm{~cm}$ pH 4-7 Immobiline Drystrips (GE Healthcare) rehydrated overnight in rehydration solution. Isoelectric focusing was performed in an Ettan IPGphor II (GE Healthcare) at $25{ }^{\circ} \mathrm{C}$ with maximum $50 \mu \mathrm{Amp} /$ strip using the following program: step $1 \mathrm{~h}$ at $150 \mathrm{~V}$, gradient $1 \mathrm{~h}$ to $500 \mathrm{~V}$, step $2 \mathrm{~h}$ at $500 \mathrm{~V}$, gradient $7 \mathrm{~h}$ to $1000 \mathrm{~V}$, gradient $4 \mathrm{~h}$ to $8000 \mathrm{~V}$, step $5 \mathrm{~h} 8000 \mathrm{~V}$.

After focusing, proteins in IPG-strips were reduced with DTT $(10 \mathrm{mg} / \mathrm{ml}$ in equilibration buffer composed of 50 mM Tris, 6 M Urea, 30 \% glycerol, 2 \% SDS, pH 8.8) for $15 \mathrm{~min}$ followed by alkylation $15 \mathrm{~min}$ with iodoacetamide ( $25 \mathrm{mg} / \mathrm{ml}$ in equilibration buffer). The strips were equilibrated in upper reservoir Laemmli buffer $(50 \mathrm{mM}$ Tris, $384 \mathrm{mM}$ Glycine, $0.2 \% \mathrm{w} / \mathrm{v}$ SDS) and placed on top of an acrylamide/bis (10\% T, $0.87 \%$ C) Tris- $\mathrm{HCl}, \mathrm{pH} 8.8$, gel in low fluorescent glass plates. Second dimension electrophoresis was conducted in the Ettan Dalt six gel system (GE Healthcare) program as follows: $2 \mathrm{~h}$ at $0.3 \mathrm{~W} /$ gel, $10 \mathrm{~h}$ at $1 \mathrm{~W} /$ gel, $4 \mathrm{~h}$ at $2 \mathrm{~W} /$ gel.

DIGE-gels were scanned on Typhoon 8600 scanner at a pixel resolution of $100 \mu \mathrm{m}$, the photomultiplier tubes at $600 \mathrm{~V}$ and laser and emission filters set at standard DIGE scanning. DeCyder software v. 6.0 (GE Healthcare) was used for image analysis. Spots more than 1.3 fold regulated with a $p$-value $<0.05$ were selected for spot-picking.

A preparative gel with a protein load of $400 \mu \mathrm{g}$ protein was prepared using the same conditions as described above. The gel was stained using coomassie blue G250 (Merck) and scanned (red laser, $633 \mathrm{~nm}$ ). In DeCyder the gel was aligned with the DIGE gels and regulated spots were picked using an Ettan spotpicker (GE Healthcare).

\section{Identification of proteins of interest using LC MS/MS}

Picked gel plugs were dehydrated and destained using acetonitrile and $\mathrm{NH}_{4} \mathrm{HCO}_{3}$ and the gel-plugs were dried before reswelling in $50 \mathrm{mM} \mathrm{NH} \mathrm{NCO}_{3}$ with $100 \mathrm{ng}$ trypsin (Promega) pr plug and left over night at $37{ }^{\circ} \mathrm{C}$ for in-gel digestion [66]. At the end of digestion, formic acid was added. Peptides were purified on C18 reverse phase material using Stage-tips and eluted with $2 \mu \mathrm{l}$ $70 \%$ acetonitrile into $18 \mu \mathrm{l} 0.1 \%$ formic acid. The samples were subjected to LC MS/MS using an Easy nLC (Proxeon) (50 min gradient of $5-40 \%$ acetonitrile in $0.1 \%$ formic acid) coupled in-line with a Q-TOF Ultima API mass-spectrometer (Micromass/Waters). Data were processed using MassLynx 4.0 software (Waters). MS/ MS data are searched against SwissProt (v. 2014_02) limited to human taxonomy using Mascot v. 2.3.02 (Matrix Sciences). Trypsin was selected and a maximum of one missed cleavage was allowed. The following variable modifications were accepted: Carbamidomethyl, propionamide, and oxidation on methionine. Peptide tolerance was set at 1.2 Da and MS/MS tolerance at 0.6 Da. Instrument setting was specified as ESI-QUADTOF. Protein identifications were based on significant MOWSE-score, peptide scores $>30$, low e-values, and visual inspection of MS/MS spectra. Spots were excluded from further analysis if identified as albumin, due to the use of albumin as delivery vehicle for fatty acids.

\section{Additional files}

Additional file 1: Data S1. GLC. Results from the gas-liquid chromatography analysis. On the left are in bold averages of mol\% for three biological replicates and on the right their respective standard deviations. Raw data is provided for each replicate in separate sheets. (XLSX 48 kb)

Additional file 2: Data S2. SILAC transVA-EA- cisVA. Data from the SILAC investigation of the cellular response to transVA, EA and cisVA. (XLSX $867 \mathrm{~kb}$ )

Additional file 3: Data S3. DIGE identifications. Protein identifications by LC-MS/MS from DIGE analysis of the secretomes from cells incubated with transVA, EA and cisVA. Spots with significantly different intensities between samples in the DIGE analysis were excised, and the proteins were identified by LC-MS/MS and Mascot searches. Proteins identified by $\geq 2$ unique peptides with ion scores $\geq 30$ are highlighted. (XLSX $23 \mathrm{~kb}$ )

Additional file 4: Figure S1. DIGE 2D-gel with indications of the significant differentially regulated spots in EA/transVA (panel A) and transVA/ cis $V A$ (panel B). The numbers correspond to Table 2 and supplemental data S3. (DOCX $1198 \mathrm{~kb})$

Additional file 5: Data S4. SILAC transVA-OA-CLA. Data from the SILAC investigation of the cellular response to transVA, OA and CLA. In sheet 1, "full data", unfiltered data from this second SILAC triplex is displayed. In sheet 2, "signif. 1.3 fold", proteins significantly regulated $\geq 1.3$ fold in $\geq$ one comparison are displayed. Proteins are reported with Uniprot accession number, Name, Fold regulation in individual comparisons, the geometric standard deviation (Geo.SD.), and selected GO-terms: GO:0006950 response 
to stress $(\mathrm{x})$ and GO:0002526 acute inflammatory response (y). Black bold: significant regulatory data $(p<0.01)$ with fold $>1.3$, black italic: significant regulatory data $(p<0.01)$ with fold $<1.3$, grey italic: not significant regulatory data $(p>0.01)$. (XLSX $925 \mathrm{~kb})$

\section{Abbreviations}

CLA: Conjugated linoleic acid, (trans,cis $\Delta^{9,11}$ C18:2); cis VA: cis-vaccenic acid (cis $\Delta^{11}$ C18:1); CVD: Cardiovascular disease; DIGE: Difference in-gel electrophoresis; EA: Elaidic acid (trans $\triangle^{9} \mathrm{C} 18: 1$ ); FAME: Fatty acid methyl esters; iTFA: Industrially produced TFA; OA: Oleic acid (cis $\triangle^{9} \mathrm{C} 18: 1$ ); rTFA: Ruminant TFA; SILAC: Stable isotope labeling by amino acids in cell culture; TFA: Trans fatty acid; TG: triacylglycerol; transVA: trans-vaccenic acid (trans $\Delta^{11} \mathrm{C} 18: 1$ ); Protein name abbreviations: AHSG: alpha-2-HS-glycoprotein; CO3: complement factor C3; IGFBP1: insulin-like growth factor-binding protein 1; PAl1: plasminogen activator inhibitor 1; PCSK9: proprotein convertase subtilisin/kexin type 9; TFPI: tissue factor pathway inhibitor; TIMP1: metalloproteinase inhibitor 1; TTR: transthyretin.

\section{Competing interests}

The author(s) declare that they have no competing interests.

\section{Authors' contributions}

JJE, LVN and TPK were responsible for project conception; LVN, TPK, DK, CS, and TFD performed the experiments and analyzed the data; KWS contributed to the interpretation of the data and edits of the final manuscript; TPK, LVN and JJE wrote the manuscript; and JJE had primary responsibility for the final content. All authors read and approved the final manuscript.

\section{Acknowledgements}

The Danish council for Strategic Research - Health, Food and Welfare financially supported the work. Xuebing Xu and Zheng Guo from Lipid Lab at the Department of Molecular Biology and Genetics at Aarhus University, Denmark, are acknowledged for valuable discussion on the interpretation of GC data. The mass spectrometry proteomics data have been deposited to the ProteomeXchange Consortium (http://proteomecentral.proteomexchange.org) via the PRIDE partner repository [71] with the dataset identifier PXD000760 and DOl10.6019/PXD000760.

\section{Received: 5 May 2015 Accepted: 22 November 2015}

Published online: 01 December 2015

\section{References}

1. Stender S, Dyerberg J, Astrup A. High levels of industrially produced trans fat in popular fast foods. N Engl J Med. 2006;354:1650-2.

2. Micha R, Mozaffarian D. Trans fatty acids: effects on metabolic syndrome, heart disease and diabetes. Nat Rev Endocrinol. 2009;5:335-44.

3. Mozaffarian D, Clarke R. Quantitative effects on cardiovascular risk factors and coronary heart disease risk of replacing partially hydrogenated vegetable oils with other fats and oils. Eur J Clin Nutr. 2009;63 Suppl 2:S22-33.

4. Gebauer SK, Chardigny JM, Jakobsen MU, Lamarche B, Lock AL, Proctor SD, et al. Effects of ruminant trans fatty acids on cardiovascular disease and cancer: a comprehensive review of epidemiological, clinical, and mechanistic studies. Adv Nutr. 2011;2:332-54.

5. Willett WC, Stampfer MJ, Manson JE, Colditz GA, Speizer FE, Rosner BA, et al. Intake of trans fatty acids and risk of coronary heart disease among women. Lancet. 1993;341:581-5.

6. Oomen CM, Ocke MC, Feskens EJ, van Erp-Baart MA, Kok FJ, Kromhout D. Association between trans fatty acid intake and 10-year risk of coronary heart disease in the Zutphen Elderly Study: a prospective population-based study. Lancet. 2001;357:746-51.

7. Jakobsen MU, Overvad K, Dyerberg J, Heitmann BL. Intake of ruminant trans fatty acids and risk of coronary heart disease. Int J Epidemiol. 2008;37:173-82.

8. Pietinen P, Ascherio A, Korhonen P, Hartman AM, Willett WC, Albanes D, et al. Intake of fatty acids and risk of coronary heart disease in a cohort of Finnish men. The Alpha-Tocopherol, Beta-Carotene Cancer Prevention Study. Am J Epidemiol. 1997;145:876-87.

9. Bolton-Smith C, Woodward M, Fenton S, Brown CA. Does dietary trans fatty acid intake relate to the prevalence of coronary heart disease in Scotland? Eur Heart J. 1996;17:837-45.
10. Rissanen $H$, Knekt $P$, Jarvinen $R$, Salminen I, Hakulinen T. Serum fatty acids and breast cancer incidence. Nutr Cancer. 2003;45:168-75.

11. Shannon J, King IB, Moshofsky R, Lampe JW, Gao DL, Ray RM, et al. Erythrocyte fatty acids and breast cancer risk: a case-control study in Shanghai, China. Am J Clin Nutr. 2007;85:1090-7.

12. Precht $D$, Molkentin J. Trans fatty acids: implications for health, analytical methods, incidence in edible fats and intake (a review). Nahrung. 1995;39: 343-74.

13. Kepler CR, Hirons KP, McNeill JJ, Tove SB. Intermediates and products of the biohydrogenation of linoleic acid by Butyrinvibrio fibrisolvens. J Biol Chem. 1966;241:1350-4.

14. Slots T, Butler G, Leifert C, Kristensen T, Skibsted LH, Nielsen JH. Potentials to differentiate milk composition by different feeding strategies. J Dairy Sci. 2009;92:2057-66.

15. Sebedio J-L, Ratnayake WMN. Analysis of trans mono- and polyunsaturated fatty acids. In: Dijkstra AJ, Hamilton RJ, Hamm W, editors. Trans fatty acids. Oxford; Ames, lowa: Blackwell Pub; 2008. p. 102-28.

16. Beers A, Ariaansz R, Okonek D. Trans isomer control in hydrogenation of edible oils. In: Dijkstra AJ, Hamilton RJ, Hamm W, editors. Trans fatty acids. Oxford; Ames, lowa: Blackwell Pub; 2008. p. 147-80.

17. Clifton PM, Keogh JB, Noakes M. Trans fatty acids in adipose tissue and the food supply are associated with myocardial infarction. J Nutr. 2004;134:874-9.

18. Hodgson JM, Wahlqvist ML, Boxall JA, Balazs ND. Platelet trans fatty acids in relation to angiographically assessed coronary artery disease. Atherosclerosis. 1996;120:147-54.

19. Lichtenstein AH, Erkkila AT, Lamarche B, Schwab US, Jalbert SM, Ausman LM. Influence of hydrogenated fat and butter on CVD risk factors: remnant-like particles, glucose and insulin, blood pressure and C-reactive protein. Atherosclerosis. 2003:171:97-107.

20. Motard-Belanger A, Charest A, Grenier G, Paquin P, Chouinard Y, Lemieux S, et al. Study of the effect of trans fatty acids from ruminants on blood lipids and other risk factors for cardiovascular disease. Am J Clin Nutr. 2008;87: 593-9.

21. Aro A, Jauhiainen M, Partanen R, Salminen I, Mutanen M. Stearic acid, trans fatty acids, and dairy fat: effects on serum and lipoprotein lipids, apolipoproteins, lipoprotein(a), and lipid transfer proteins in healthy subjects. Am J Clin Nutr. 1997;65:1419-26.

22. de Roos NM, Bots ML, Katan MB. Replacement of dietary saturated fatty acids by trans fatty acids lowers serum HDL cholesterol and impairs endothelial function in healthy men and women. Arterioscler Thromb Vasc Biol. 2001;21:1233-7.

23. Chardigny JM, Destaillats F, Malpuech-Brugere C, Moulin J, Bauman DE, Lock $A L$, et al. Do trans fatty acids from industrially produced sources and from natural sources have the same effect on cardiovascular disease risk factors in healthy subjects? Results of the trans Fatty Acids Collaboration (TRANSFACT) study. Am J Clin Nutr. 2008;87:558-66.

24. Iwata NG, Pham M, Rizzo NO, Cheng AM, Maloney E, Kim F. Trans fatty acids induce vascular inflammation and reduce vascular nitric oxide production in endothelial cells. Plos One. 2011;6:e29600.

25. Jaudszus A, Jahreis G, Schlormann W, Fischer J, Kramer R, Degen C, et al. Vaccenic acid-mediated reduction in cytokine production is independent of C9, t11-CLA in human peripheral blood mononuclear cells. Biochim Biophys Acta. 1821;2012:1316-22.

26. Lopes SM, Trimbo SL, Mascioli EA, Blackburn GL. Human plasma fatty acid variations and how they are related to dietary intake. Am J Clin Nutr. 1991; 53:628-37.

27. Swagell CD, Henly DC, Morris CP. Regulation of human hepatocyte gene expression by fatty acids. Biochem Biophys Res Commun. 2007;362:374-80.

28. Kondoh Y, Kawada T, Urade R. Activation of caspase 3 in HepG2 cells by elaidic acid (t18:1). Biochim Biophys Acta. 2007;1771:500-5.

29. Vock C, Gleissner M, Klapper M, Doring F. Identification of palmitateregulated genes in HepG2 cells by applying microarray analysis. Biochim Biophys Acta. 2007;1770:1283-8.

30. Moberly JB, Cole TG, Alpers DH, Schonfeld G. Oleic acid stimulation of apolipoprotein B secretion from HepG2 and Caco-2 cells occurs post-transcriptionally. Biochim Biophys Acta. 1990;1042:70-80.

31. Vock C, Gleissner M, Klapper M, Doring F. Oleate regulates genes controlled by signaling pathways of mitogen-activated protein kinase, insulin, and hypoxia. Nutr Res. 2008;28:681-9.

32. Dashti N, Feng Q, Franklin FA. Long-term effects of cis and trans monounsaturated (18:1) and saturated (16:0) fatty acids on the synthesis 
and secretion of apolipoprotein A-I- and apolipoprotein B-containing lipoproteins in HepG2 cells. J Lipid Res. 2000;41:1980-90.

33. Arrol S, Mackness MI, Durrington PN. The effects of fatty acids on apolipoprotein B secretion by human hepatoma cells (HEP G2). Atherosclerosis. 2000;150:255-64.

34. Vinciguerra M, Carrozzino F, Peyrou M, Carlone S, Montesano R, Benelli R, et al. Unsaturated fatty acids promote hepatoma proliferation and progression through downregulation of the tumor suppressor PTEN.

J Hepatol. 2009;50:1132-41.

35. Turpeinen AM, Mutanen M, Aro A, Salminen I, Basu S, Palmquist DL, et al. Bioconversion of vaccenic acid to conjugated linoleic acid in humans. Am J Clin Nutr. 2002;76:504-10.

36. Ix JH, Chertow GM, Shlipak MG, Brandenburg VM, Ketteler M, Whooley MA. Association of fetuin-A with mitral annular calcification and aortic stenosis among persons with coronary heart disease: data from the Heart and Soul Study. Circulation. 2007;115:2533-9.

37. Krogager TP, Nielsen LV, Bak S, Young C, Ferreri $C$, Jensen ON, et al. Identification of a potential biomarker panel for the intake of the common dietary trans fat elaidic acid (trans9-C18:1). J Proteomics. 2012;75:2685-96.

38. Vendel Nielsen L, Krogager TP, Young C, Ferreri C, Chatgilialoglu C, Norregaard Jensen $\mathrm{O}$, et al. Effects of elaidic acid on lipid metabolism in HepG2 cells, investigated by an integrated approach of lipidomics, transcriptomics and proteomics. PLoS One. 2013;8:e74283.

39. Du ZY, Degrace P, Gresti J, Loreau O, Clouet P. Vaccenic and elaidic acid equally esterify into triacylglycerols, but differently into phospholipids of fed rat liver cells. Lipids. 2011;46:647-57.

40. Du ZY, Degrace P, Gresti J, Loreau O, Clouet P. Dissimilar properties of vaccenic versus elaidic acid in beta-oxidation activities and gene regulation in rat liver cells. Lipids. 2010;45:581-91.

41. Yu W, Liang X, Ensenauer RE, Vockley J, Sweetman L, Schulz H. Leaky beta-oxidation of a trans-fatty acid: incomplete beta-oxidation of elaidic acid is due to the accumulation of 5-trans-tetradecenoyl-CoA and its hydrolysis and conversion to 5 -trans-tetradecenoylcarnitine in the matrix of rat mitochondria. J Biol Chem. 2004;279:52160-7.

42. Qian YW, Schmidt RJ, Zhang Y, Chu S, Lin A, Wang H, et al. Secreted PCSK9 downregulates low density lipoprotein receptor through receptor-mediated endocytosis. J Lipid Res. 2007:48:1488-98.

43. Lagrost L. Differential effects of cis and trans fatty acid isomers, oleic and elaidic acids, on the cholesteryl ester transfer protein activity. Biochim Biophys Acta. 1992;1124:159-62.

44. Kohler HP, Grant PJ. Plasminogen-activator inhibitor type 1 and coronary artery disease. N Engl J Med. 2000;342:1792-801.

45. Heald AH, Cruickshank JK, Riste LK, Cade JE, Anderson S, Greenhalgh A, et al. Close relation of fasting insulin-like growth factor binding protein-1 (IGFBP-1) with glucose tolerance and cardiovascular risk in two populations. Diabetologia. 2001;44:333-9.

46. Laughlin GA, Barrett-Connor E, Criqui MH, Kritz-Silverstein D. The prospective association of serum insulin-like growth factor I (IGF-I) and IGF-binding protein1 levels with all cause and cardiovascular disease mortality in older adults: the Rancho Bernardo Study. J Clin Endocrinol Metab. 2004;89:1 14-20.

47. Kronenberg F, Stuhlinger M, Trenkwalder E, Geethanjali FS, Pachinger O, von Eckardstein A, et al. Low apolipoprotein A-IV plasma concentrations in men with coronary artery disease. J Am Coll Cardiol. 2000;36:751-7.

48. Ross R. Atherosclerosis-an inflammatory disease. N Engl J Med. 1999;340: 115-26.

49. Baer DJ, Judd JT, Clevidence BA, Tracy RP. Dietary fatty acids affect plasma markers of inflammation in healthy men fed controlled diets: a randomized crossover study. Am J Clin Nutr. 2004;79:969-73.

50. Lopez-Garcia E, Schulze MB, Meigs JB, Manson JAE, Rifai N, Stampfer MJ, et al. Consumption of Trans fatty acids is related to plasma biomarkers of inflammation and endothelial dysfunction. J Nutr. 2005;135:562-6.

51. Muscari A, Massarelli G, Bastagli L, Poggiopollini G, Tomassetti V, Drago G, et al. Relationship of serum C3 to fasting insulin, risk factors and previous ischaemic events in middle-aged men. Eur Heart J. 2000;21:1081-90.

52. Halkes CJ, van Dijk H, de Jaegere PP, Plokker HW, van Der Helm Y, Erkelens DW, et al. Postprandial increase of complement component 3 in normolipidemic patients with coronary artery disease: effects of expanded-dose simvastatin. Arterioscler Thromb Vasc Biol. 2001;21:1526-30.

53. Forneris F, Ricklin D, Wu J, Tzekou A, Wallace RS, Lambris JD, et al. Structures of $\mathrm{C} 3 \mathrm{~b}$ in complex with factors $\mathrm{B}$ and $\mathrm{D}$ give insight into complement convertase formation. Science. 2010;330:1816-20.
54. Hourcade DE, Mitchell LM, Oglesby TJ. Mutations of the type A domain of complement factor B that promote high-affinity C3b-binding. J Immunol. 1999;162:2906-11.

55. Ritchie GE, Moffatt BE, Sim RB, Morgan BP, Dwek RA, Rudd PM. Glycosylation and the complement system. Chem Rev. 2002;102:305-320-319.

56. Stec JJ, Silbershatz H, Tofler GH, Matheney TH, Sutherland P, Lipinska I, et al. Association of fibrinogen with cardiovascular risk factors and cardiovascular disease in the Framingham Offspring Population. Circulation. 2000;102:1634-8.

57. Baugh RJ, Broze Jr GJ, Krishnaswamy S. Regulation of extrinsic pathway factor Xa formation by tissue factor pathway inhibitor. J Biol Chem. 1998, 273:4378-86.

58. Girard TJ, Warren LA, Novotny WF, Likert KM, Brown SG, Miletich JP, et al. Functional significance of the Kunitz-type inhibitory domains of lipoproteinassociated coagulation inhibitor. Nature. 1989;338:518-20.

59. Aihara K, Azuma H, Takamori N, Kanagawa Y, Akaike M, Fujimura M, et al. Heparin cofactor II is a novel protective factor against carotid atherosclerosis in elderly individuals. Circulation. 2004;109:2761-5.

60. Weggemans RM, Rudrum M, Trautwein EA. Intake of ruminant versus industrial trans fatty acids and risk of coronary heart disease - what is the evidence? Eur J Lipid Sci Technol. 2004;106:390-7.

61. Couloubaly S, Delomenie C, Rousseau D, Paul JL, Grynberg A, Pourci ML. Fatty acid incorporation in endothelial cells and effects on endothelial nitric oxide synthase. Eur J Clin Invest. 2007;37:692-9.

62. Matyash V, Liebisch G, Kurzchalia TV, Shevchenko A, Schwudke D. Lipid extraction by methyl-tert-butyl ether for high-throughput lipidomics. J Lipid Res. 2008:49:1137-46.

63. Kronvall G, Simmons A, Myhre EB, Jonsson S. Specific absorption of human serum albumin, immunoglobulin $A$, and immunoglobulin $G$ with selected strains of group A and G streptococci. Infect Immun. 1979;25:1-10.

64. Bradford MM. A rapid and sensitive method for the quantitation of microgram quantities of protein utilizing the principle of protein-dye binding. Anal Biochem. 1976;72:248-54.

65. Bury AF. Analysis of protein and peptide mixtures : Evaluation of three sodium dodecyl sulphate-polyacrylamide gel electrophoresis buffer systems. J Chromatogr A. 1981;213:491-500.

66. Shevchenko A, Tomas H, Havlis J, Olsen JV, Mann M. In-gel digestion for mass spectrometric characterization of proteins and proteomes. Nat Protoc. 2006;1:2856-60.

67. Perkins DN, Pappin DJ, Creasy DM, Cottrell JS. Probability-based protein identification by searching sequence databases using mass spectrometry data. Electrophoresis. 1999;20:3551-67.

68. Dyrlund TF, Poulsen ET, Scavenius C, Sanggaard KW, Enghild JJ. MS Data Miner: a web-based software tool to analyze, compare, and share mass spectrometry protein identifications. Proteomics. 2012:12:2792-6.

69. Huang DW, Sherman BT, Lempicki RA. Systematic and integrative analysis of large gene lists using DAVID bioinformatics resources. Nat Protoc. 2009;4 44-57.

70. Huang DW, Sherman BT, Lempicki RA. Bioinformatics enrichment tools: paths toward the comprehensive functional analysis of large gene lists. Nucleic Acids Res. 2009:37:1-13.

71. Vizcaino JA, Cote RG, Csordas A, Dianes JA, Fabregat A, Foster JM, et al. The PRoteomics IDEntifications (PRIDE) database and associated tools: status in 2013. Nucleic Acids Res. 2013:41:D1063-9.

\section{Submit your next manuscript to BioMed Central and we will help you at every step:}

- We accept pre-submission inquiries

- Our selector tool helps you to find the most relevant journal

- We provide round the clock customer support

- Convenient online submission

- Thorough peer review

- Inclusion in PubMed and all major indexing services

- Maximum visibility for your research

Submit your manuscript at www biomedcentral com/submit 